\title{
BIMBINGAN PRAKTIKUM KIMIA UJI INDIKATOR ALAMI DI SMA NEGERI 1 SINGOSARI
}

\author{
Nurin Fitriana ${ }^{1}$, Muslimatul Mufida ${ }^{2}$ \\ ${ }^{1,2}$ Universitas Wisnuwardhana Malang \\ nurin.unidha@gmail.com
}

\begin{abstract}
Practicum activities in learning Natural Sciences in the school environment is one of the effective methods to achieve learning objectives. Because in learning activities there are many concepts that can be explained if students carry out scientific activities or with laboratory tests. Singosari 1 High School is one of the high schools located on Jl. Ki Hajar Dewantara Singosari, Malang Regency. This community service activity aims to provide practical guidance to students in SMA Negeri 1 Singosari for Chemistry subjects. This is based on the results of interviews with chemistry teachers who showed that many students had difficulty in acid-base material. The method used needs analysis and is measured with quantitative data in the form of a tabulated questionnaire. The results of this service can be measured qualitatively and quantitatively, namely a questionnaire given to students that shows that there is a positive response and most feel very satisfied with the practicum activities undertaken. Students feel they can construct their understanding independently.
\end{abstract}

Keywords: Practicum, acid-base, IPA

\section{PENDAHULUAN}

Sekolah Menengah Atas Negeri 1 Singosari merupakan salah satu sekolah menengah atas yang berada di Jl.Ki Hajar Dewantara Singosari Kabupaten Malang. Kepala Sekolah SMAN 1 Singosari adalah Bapak Dr. Abdul Tedy, M.Pd. Terdapat 12 rombel kelas X, 12 rombel kelas XI dan 12 rombel kelas XII. Di sekolah ini memiliki 5 guru pengajar di bidang mata pelajaran Kimia. Ilmu kimia merupakan konsep abstrak dan memerlukan media belajar yang memfasilitasi kegiatan pembelajaran. Dalam kimia larutan, diperlukan pembuktian teori dari ataupun uji larutan dalam kegiatan praktikum. Pembelajaran IPA tidak akan terpisahkan dari kegiatan praktikum. Beberapa hal yang melandasi pentingnya kegiatan praktikum IPA. Pertama, praktikum dapat membangkitkan motivasi belajar IPA. Kedua, praktikum mengembangkan keterampilan dasar melakukan eksperimen. Ketiga, praktikum menjadi wahana belajar pendekatan ilmiah. Keempat, praktikum menunjang materi pelajaran. Keterampilan proses IPA sendiri meliputi: mengamati, menafsirkan, mengklasifikasikan, menggunakan alat dan bahan, menerapkan konsep,merencanakan percobaan, berkomunikasi dan mengajukan pertanyaan. Metode praktikum merupakan penunjang kegiatan proses belajar untuk menemukan prinsip tertentu atau menjelaskan tentang prinsip-prinsip yang dikembangkan.

Pembelajaran dengan pendekatan saintifik menegaskan bahwa siswa diajakuntuk bekerja sains, dalam artian siswa diberi keleluasaan untuk terampil dalam proses ilmiah (Marta et al., 2018). Dalam kegiatannya dimulai dari mengamati fenomena ilmiah kemudian mengamati permasalahan yang ditemui kemuadian melakukan kegiatan pengambilan kesimpulan dalam fenomena yang dihadapi dengan kegiatan diskusi dalam praktikum juga akan menjadikan kegiatan mandiri bagi pebelajar. Kegiatan diskusi 
tersebut, secara tidak langsung memfasilitasi mahasiswa untuk mengkonstruksi pengetahuannya sendiri (N. Fitriana, 2018).

Kegiatan praktikum dalam pembelajaran Ilmu Pengetahuan Alam merupakan salah satu metode yang efektif untuk mencapai tujuan pembelajaran. Karena dalam kegiatan belajarnya banyak konsep yang dapat dijelaskan jika siswa melakukan kegiatan ilmiah atau dengan uji laboratorium. Dengan praktikum, kegiatan pembelajaran dapat memberi kesempatan siswa untuk menguji dan mengaplikasikan teori dengan menggunakan fasilitas laboratorium ataupun dengan bahan di luar laboratorium. Selain itu dapat menerapkan proses kerja ilmiah dan keselamatan kerja di laboratorium melalui pengamatan dan percobaan untuk memahami permasalahan sains pada berbagai objek, mengkomunikasikan hasil pengamatan dan percobaan secara lisan maupun tulisan, serta dapat menyajikan data berbagai objek berdasarkan pengamatan dan percobaan dengan menerapkan prosedur ilmiah. Pada kegiatan praktikum, siswa dapat melakukan kegiatan mengamati, menafsirkan data, meramalkan, menggunakan alat dan bahan, merencanakan praktikum, mengkomunikasikan hasil praktikum dan mengajukan pertanyaan (Suryaningsih, 2017).

Dalam reaksi asam basa, penetuan sifatnya dapat ditentukan menggunakan indikator alami, yaitu bahan-bahan alam yang dapat berubah warnanya dalam larutan asam, basa, dan netral. Indikator alam yang biasanya dilakukan dalam pengujian asam basa adalah tumbuhan yang berwarna mencolok, berupa bunga-bungaan, umbi-umbian, kulit buah, dan dedaunan. Perubahan warna indikator bergantung pada warna jenis tanamannya, misalnya kembang sepatu merah di dalam larutan asam akan berwarna merah dan di dalam larutan basa akan berwarna hijau, kol ungu di dalam larutan asam akan berwarna merah keunguan dan di dalam larutan basa akan berwarna hijau.

Pada umumnya, senyawa basa mempunyai rasa pahit dan senyawa asam mempunyai rasa asam. Namun begitu, tidak dianjurkan untuk mengenali asam dan basa dengan cara mencicipinya, sebab banyak di antaranya yang dapat merusak kulit (korosif) atu bahkan bersifat racun. Asam dan basa dapat dikenali dengan menggunakan zat indikator, yaitu zat yang memberi warna berbeda dalam lingkungan asam dan lingkungan basa (zat yang warnanya dapat berubah saat berinteraksi atau bereaksi dengan senyawa asam maupun senyawa basa).

Dengan suatu indikator, dapat diperoleh dari alam dan dari bahan buatan, sehingga kita dapat menentukan suatu larutan bersifat asam, basa, atau netral. Dengan indikator universal kita dapat menentukan $\mathrm{pH}$ suatu larutan. Indikator universal adalah campuran dari beberapa macam indikator yang telah distandarisasi warnanya pada $\mathrm{pH} 0-14$. Oleh karena itu, dengan mencocokkan warna indikator universal dalam suatu larutan dengan warna standart, kita dapat memperkirakan pH larutan tersebut. Di sekitar lingkungan kita, terdapat beberapa zat warna alami yang dapat digunakan sebagai indikator, seperti kunyit, ekstrak daun mahkota bunga berwarna, dengan syarat dapat mengalami perubahan warna dalam suasana yang berbeda. Tujuan dari kegiatan pengabdian ini untuk memberikan solusi kepada pihak sekolah khususnya guru kimia dalam mempermudah mengajarkan materi pengujian indicator bahan kimia. Manfaat bagi siswa, dapat menambah kemampuan konstruktivistik penegetahuan siswa pada bab pengujian indicator yang berpengaruh pada materi selanjutnya yaitu asam basa, larutan penyangga dan hidrolisis. 


\section{METODE}

Berdasarkan analisis situasi yang dihadapi di lapangan tersebut, perlu adanya program yang lebih kreatif antara mitra, tim pengususl dan pelaksana lapangan untuk melaksanakan Program Kemitraan Masyarakat ini. Berkenaan dengan hal itu, untuk memberikan solusi pada permasalahan-permasalahan tersebut, langkah awal yang dilakukan dalam program kemitraan masyarakat ini adalah need analysis (Analisa kebutuhan) (N. F. Fitriana et al., 2019). Data yang diperoleh agar terukur, dilakukan analisis kuantitatif berupa angket dengan skala likert. Dari data tersebut dapat di analisis secara kualitatif. Hal ini menjadikan kegiatan pengabdian masyarakat yang dilakukan dapat diketahui peningkatan dan kebermanfaatannya.

Prosedur pelaksanaan kegiatan yang dilakukan:

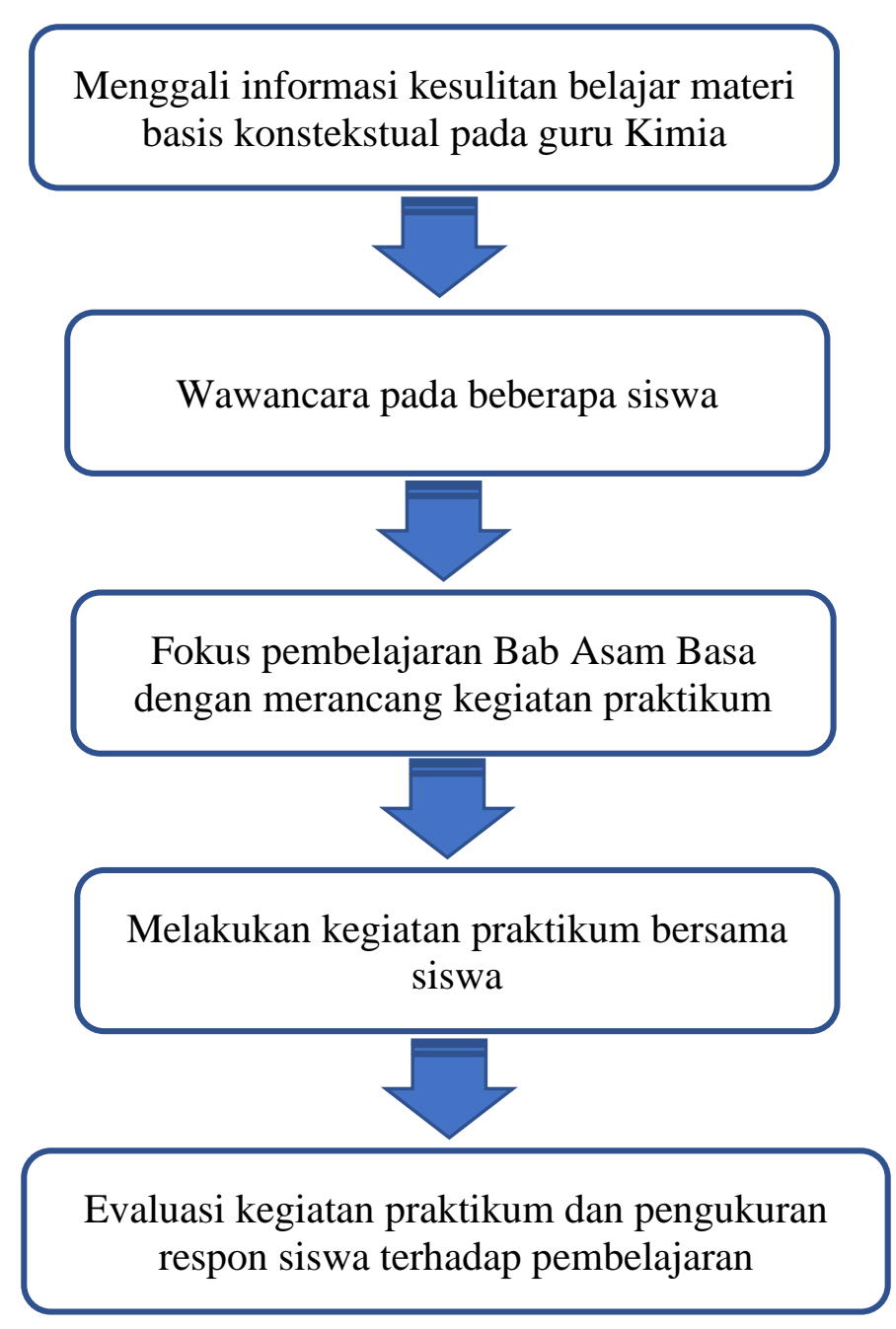

Gambar 1. Skema kegiatan pengabdian

Agar hasil pengabdian masyarakat memiliki hasil yang terukur, maka sebagai evaluasi dilakukan wawancara dan pengisian angket kepuasan siswa tentang hasil pembelajaran dengan metode praktukum. 


\section{HASIL DAN PEMBAHASAN}

Kegiatan belajar dengan pendekatan keterampilan proses dapat mempermudah siswa dalam mempelajari konsep yang menjadi tujuan belajar sains. Selain itu dapat mengembangkan keterampilan-keterampilan dasar sains, sikap ilmiah dan sikap kritis. Dalam kegiatan pembelajaran dengan praktikum memiliki peran dalam pengembangan keterampilan proses sains. Penerapan keterampilan proses sains sekaligus pengembangan sikap ilmiah yang mendukung proses pengetahuan dalam diri siswa sangat dimungkinkan dalam kegiatan praktik, sehingga dalam pelajaran sains khususnya dalam hal ini dalam kegiatan pengujian sifat asam basa dalam mata pelajaran Kimia, kegiatan praktikum memiliki kedudukan yang sangat penting. Menurut Arifin (2003), keuntungan menggunakan metode eksperimen atau praktikum adalah sebagai berikut:

a) Dapat menggambarkan keadaan yang konkret tentang suatu peristiwa

b) Siswa dapat mengamati proses.

c) Siswa dapat mengembangkan keterampilan inkuiri.

d) Siswa dapat mengembangkan sikap ilmiah.

e) Membantu guru untuk mencapai tujuan pembelajaran lebih efektif dan efisien.

Secara umum, asam memiliki sifat kaustik, rasanya pahit, licin seperti sabun, nilai $\mathrm{pH}$ lebih dari air suling, mengubah warna lakmus merah menjadi biru, dapat menghantarkan arus listrik

Basa adalah zat-zat yang dapat menetralkan asam. Secara kimia, asam dan basa saling berlawanan (El Islami et al., 2016) . Basa yang larut dalam air disebut alkali. Jika zat asam menghasilkan ion hidrogen $(\mathrm{H}+)$ yang bermuata positif, maka basa menghasilkan ion $(\mathrm{OH}-)$ yang bermuatan negatif. Secara umum senyawa basa memiliki ciri-ciri sebagai berikut:

a) Jika dilarutkan ke dalam air menghasilkan ion hidroksida $\left(\mathrm{OH}^{-}\right)$

b) Mempunyai rasa pahit

c) Terasa licin jika terkena air, misalnya sabun

d) Dapat menghantarkan arus listrik (konduktor)

e) Bersifat kaustik artinya dapat merusak kulit

f) Dapat merubah warna indikator kertas lakmus merah menjadi biru

g) Memiliki pH lebih dari 7. Semakin besar nilah pH suatu zat maka semakin kuat derajat kebasaanya.

Dalam pokok bahasan Asam Basa dalam penentuan indikator alami adalah langkah utama yang harus dimiliki oleh siswa terkait kegiatan konstruktivistik pengetahuan mereka untuk mengetahui sifat asam basa. Hal ini menjadi langkah penting karena dalam perhitungan $\mathrm{pH}$ asam basa juga mengharuskan siswa unyuk dapat memprediksi awal sifat keasaman suatu zat. Prosedur kegiatan yang dilakukan oleh siswa dalam pengujian sampel dengan indikator alami adalah sebagai berikut: 
PEDULI: Jurnal Ilmiah Pengabdian Pada Masyarakat, 2020, Vol.4, No.1

ISSN: 25974653. e-ISSN:25974688

http://peduli.wisnuwardhana.ac.id/index.php/peduli/index

Menyiapkan larutan pengganti alami larutan asam dan basa

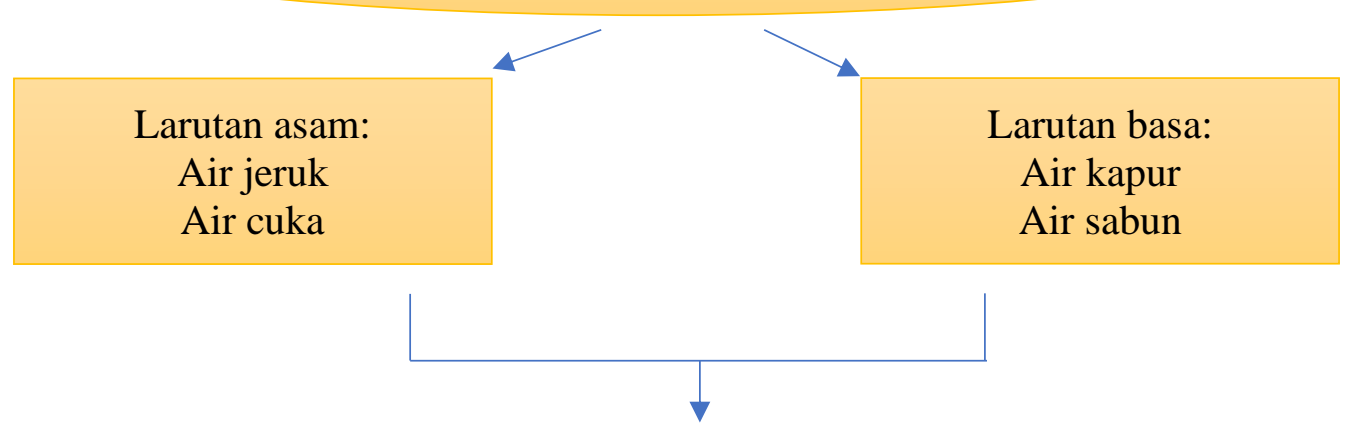

Sampel digerus +sedikit air, dengan pipet tetes di letakkan pada plat tetes

Masing-masing lubang pada plat tetes diberi larutan penguji asam dan basa

Mencatat perubahan warnanya

Gambar 2. Ringkasan prosedur praktikum

Dalam kegiatan ini terdapat beberapa langkah, yaitu:

1. Kegiatan studi literatur, bertujuan untuk menggali informasi dengan cara berkelompok sehingga kegiatan konstruksi pengetahuan antar teman sebaya dapat berjalan dengan lancar. 
PEDULI: Jurnal Ilmiah Pengabdian Pada Masyarakat, 2020, Vol.4, No.1

ISSN: 25974653. e-ISSN:25974688

http://peduli.wisnuwardhana.ac.id/index.php/peduli/index

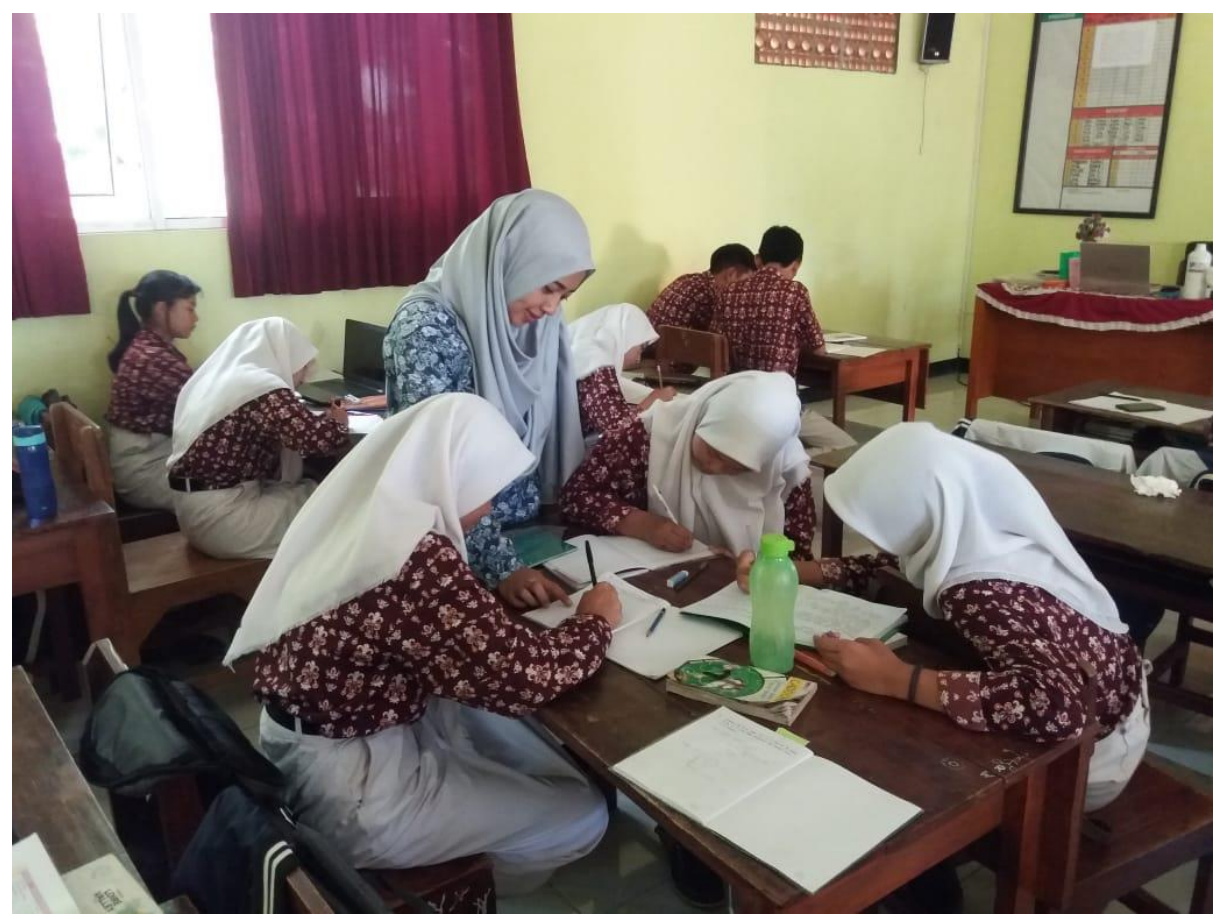

Gambar 3. Diskusi siswa studi literatur

2. Mengidentifikasi zat-zat yang dapat dijadikan indikator alami.

Sesuai hasil studi literatur yang dilakukan pada pertemuan sebelumnya, siswa mengidentifikasi sampel yang akan diuji sesuai teori yang sudah dipelajari.

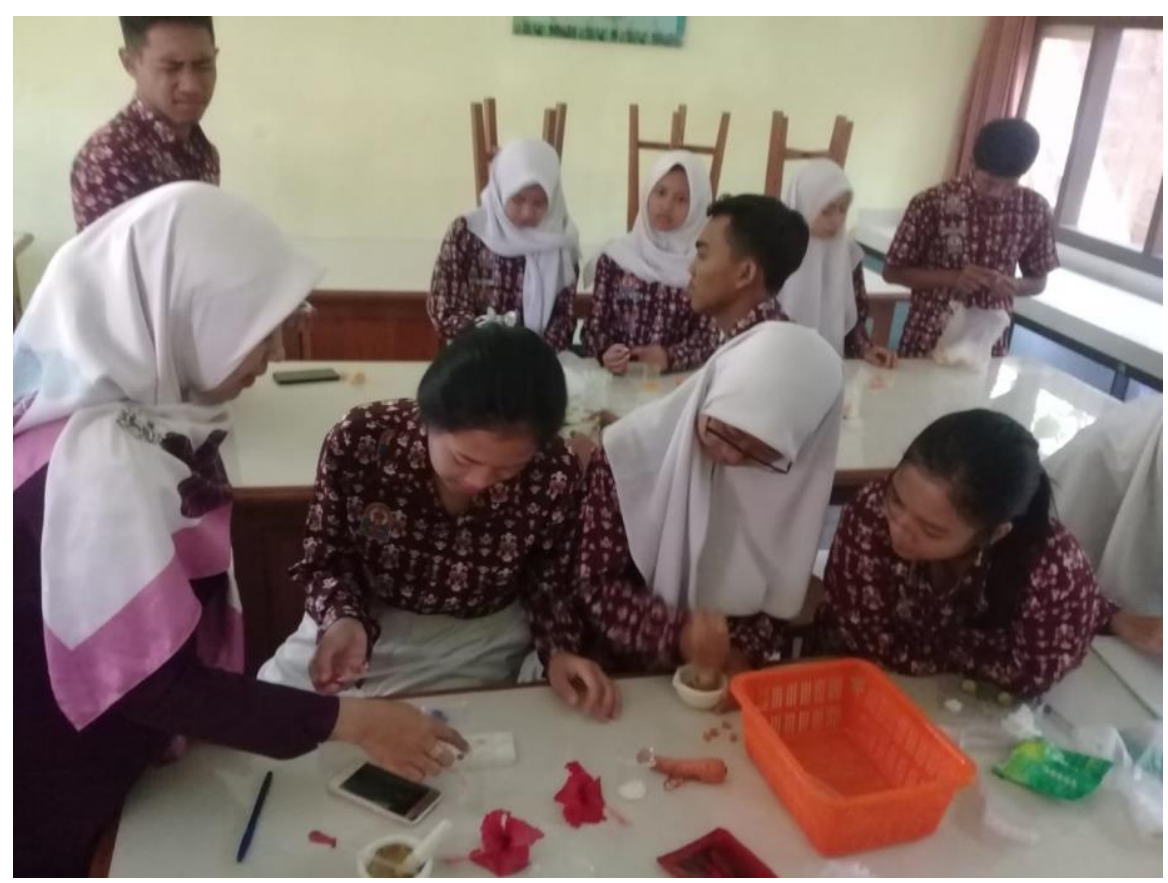

Gambar 4. Kegiatan identifikasi 
PEDULI: Jurnal Ilmiah Pengabdian Pada Masyarakat, 2020, Vol.4, No.1

ISSN: 25974653. e-ISSN:25974688

http://peduli.wisnuwardhana.ac.id/index.php/peduli/index

3. Melakukan percobaan dan uji coba pada beberapa larutan dengan indikator alami

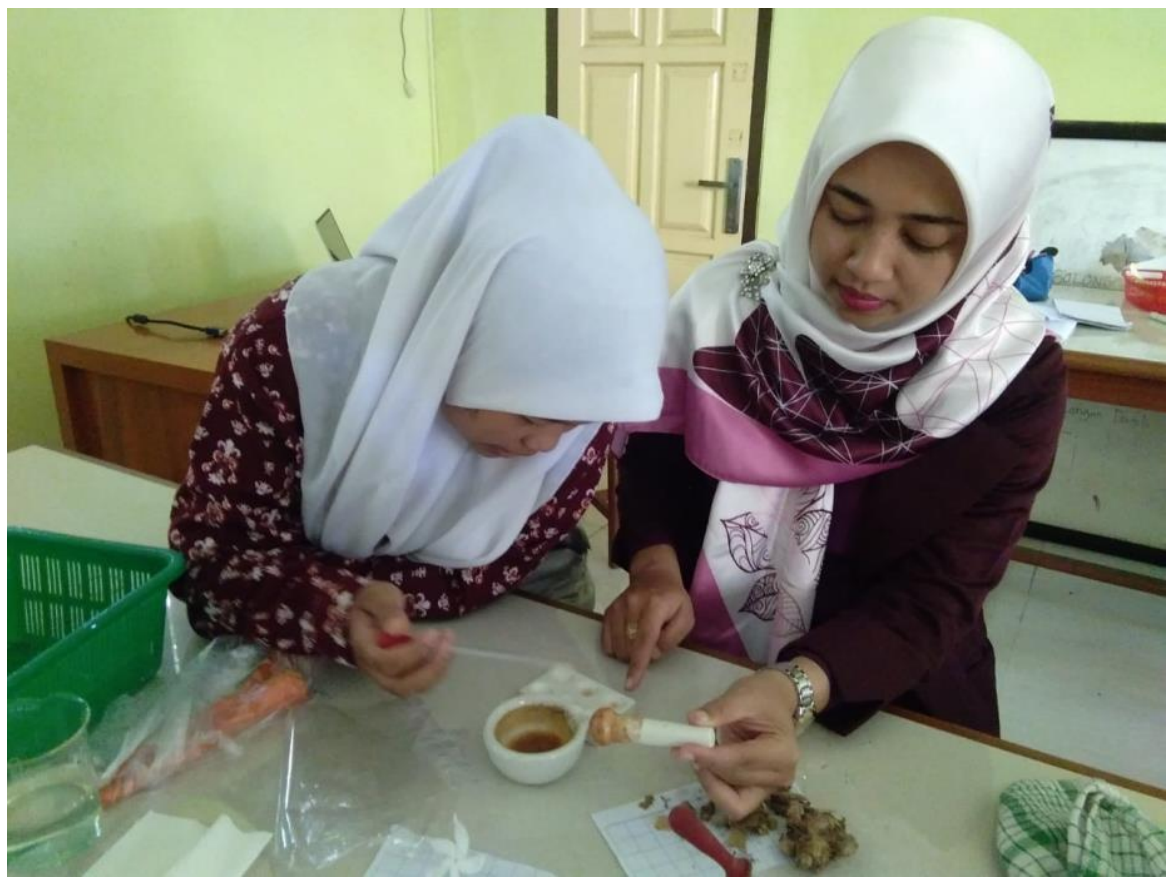

Gambar 5. Kegiatan penggerusan sampel yang akan di uji

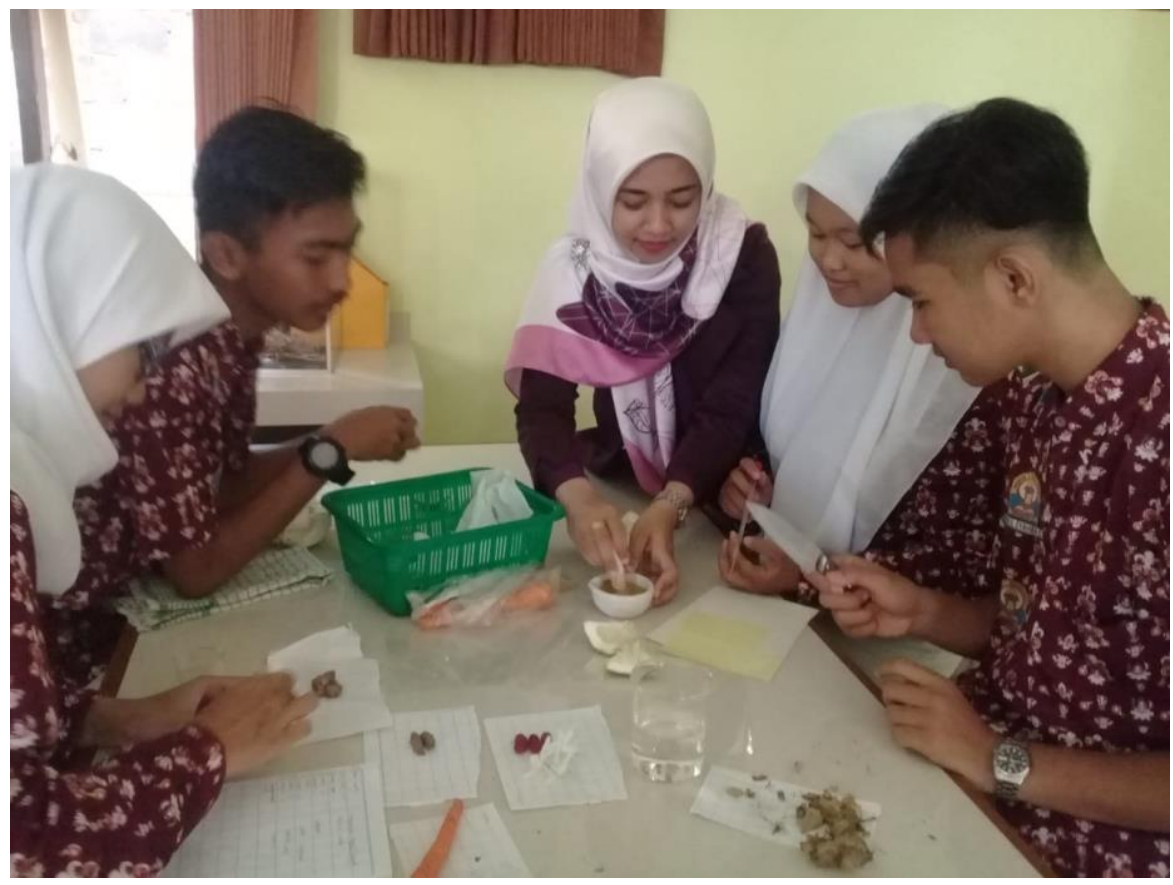

Gambar 6. Penjelasan pelaksana pengabdian pada mitra sekolah atau siswa 
PEDULI: Jurnal Ilmiah Pengabdian Pada Masyarakat, 2020, Vol.4, No.1

ISSN: 25974653. e-ISSN:25974688

http://peduli.wisnuwardhana.ac.id/index.php/peduli/index

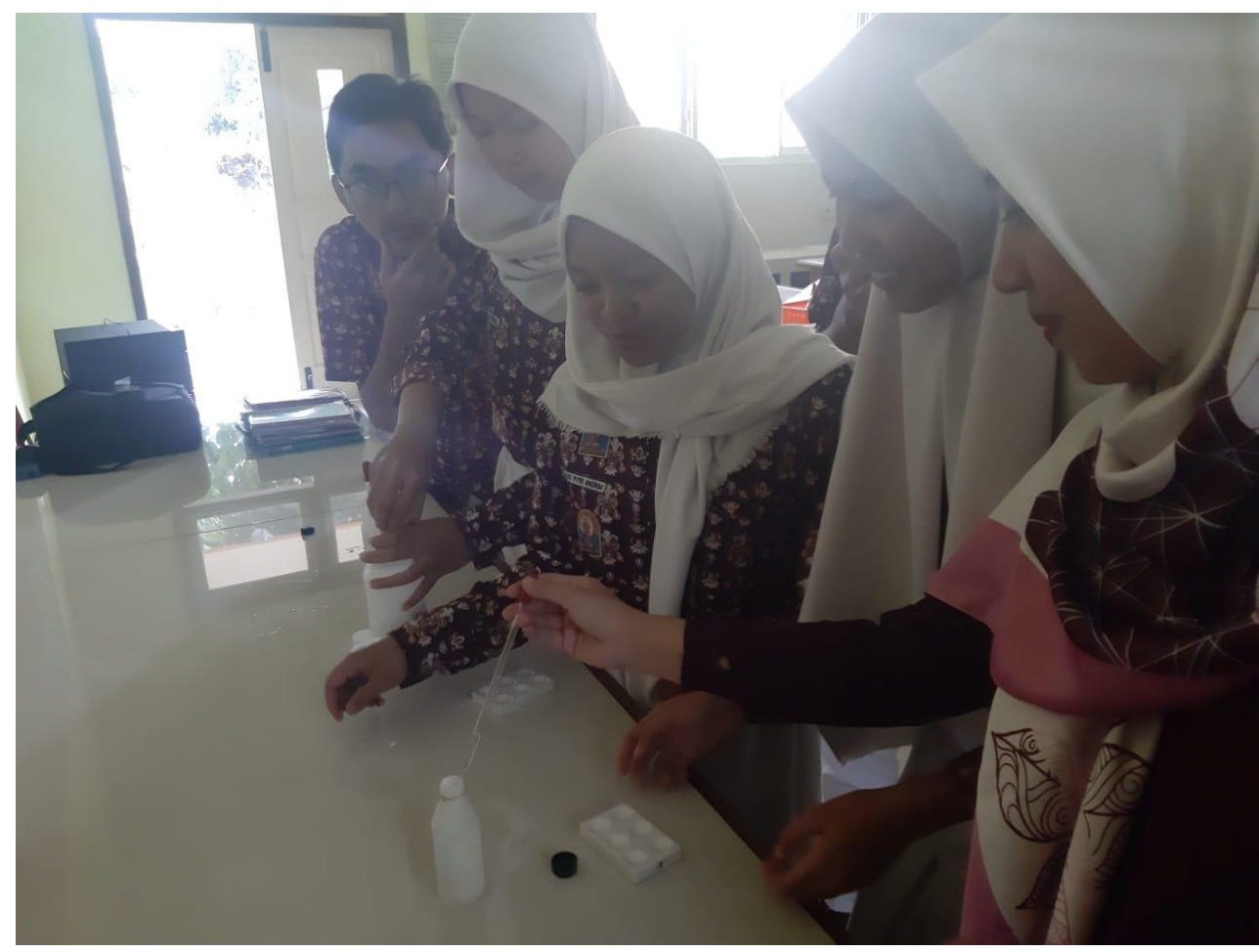

Gambar 7. Pengujian dengan bahan kimia asam lemah

4. Hasil uji warna zat asam basa yang diuji dengan indicator alami.

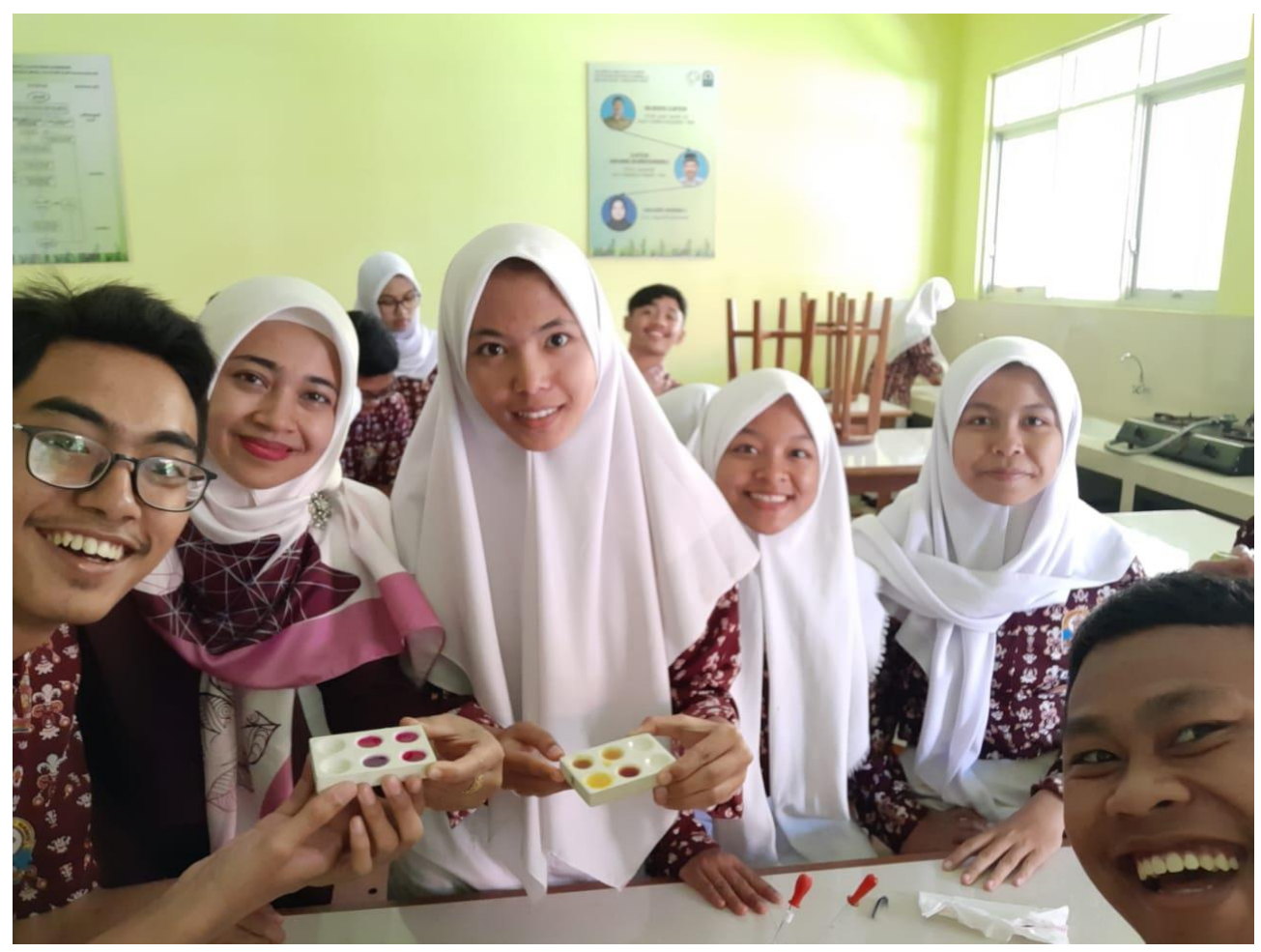

Gambar 8. Pelaksana Pengabdian bersama siswa 
Berdasarkan hasil praktikum yang dilakukan siswa tentang kimia materi uji indikator alami dalam zat yang bersifat asam dan basa, diperoleh hasil sebagai berikut:

\begin{tabular}{|c|c|c|c|c|c|}
\hline No & Sampel & +air jeruk & +air cuka & +air sabun & +air kapur \\
\hline 1 & Kulit manggis & Orange & Oranye & Merah bata & Coklat muda \\
\hline 2 & Wortel & Orange & Orange muda & Orange & Orange \\
\hline 3 & Kembang telang & Ungu muda & Biru muda & Biru pudar & Hijau Tua \\
\hline 4 & Kembang sepatu & Merah muda & Merah muda & $\begin{array}{l}\text { Hujau } \\
\text { kebiruan }\end{array}$ & Hijau tua \\
\hline 5 & Buah Beat & $\begin{array}{l}\text { Merah } \\
\text { keunguan }\end{array}$ & $\begin{array}{l}\text { Merah } \\
\text { keunguan }\end{array}$ & $\begin{array}{l}\text { Merah } \\
\text { keunguan }\end{array}$ & Merah \\
\hline 6 & Bougenville & Merah muda & Merah muda & Nila & Kuning \\
\hline 7 & Kunyit & Oranye & Oranye & Coklat & $\begin{array}{l}\text { Coklat } \\
\text { kehitaman }\end{array}$ \\
\hline 8 & Kol ungu & Merah muda & Biru tua & Biru muda & Hijau muda \\
\hline
\end{tabular}

Berdasarkan hasil percobaan, ekstrak mahkota bunga yang palik baik digunakan sebagai indikator asam basa adalah ekstrak mahkota bunga sepatu karena ketika dilarutkan dengan larutan basa (air sabun, air kapur) menunjukan gejala dengan perubahan warna menjadi hijau. Dan ketika dilarutkan dengan larutan asam (air jeruk, air cuka ) akan menunjukan gejala dengan berwarna merah.

Seperti pada ekstrak bunga dadap merah dapat digunakan sebagai indikator asambasa. Indikator ekstrak bunga dadap merah mempunyai kemiripan dengan indikator fenolftalein, sehingga dapat sebagai alternatif pengganti indikator tersebut dan dapat diaplikasikan sebagai indikator pada titrasi asam-basa tepatnya pada titrasi asam kuatbasa kuat dan asam lemah-basa kuat (Rahmawati et al., 2017).

Tidak semua tumbuhan berwarna dapat menjadi indikator yang baik dalam penentuan asam dan basa, tumbuhan dengan warna yang mencolok yang dapat dijadikan sebagai indikator yang baik, hal ini karena pada kelopak bunga tumbuhan memiliki pigmen sehingga ketika diekstrak menghasilkan berbagai warna. Menggunakan bunga yang dari jenis yang sama belum tentu sama dan bisa menjadi indikator asam-basa. Indikator asam-basa yang baik dapat memperlihatkan warna berbeda dalam larutan yang bersifat asam dan larutan yang bersifat basa.

Beberapa jenis bunga yang dapat di gunakan menjadi indikator alami adalah bunga kembang sepatu (merah), terompet (ungu), kunyit (kuning) karna saat di campur larutan asam basa berubah warna dari warna asli bunga. Bunga yang tidak dapat menjadi indikator asam-basa adalah bunga kamboja (kuning), melati (putih), dan roben oren karna saat di campur larutan asam basa bunga tersebut tidak berubah/menghasilkan warna yg mencolok. Kesimpulan yang dapat ditarik dari percobaan berdasarkan perubahan warna adalah:

1. Bahwa air jeruk dan cuka bersifat asam, sedangkan air sabun dan air kapur bersifat basa.

2. Indikator asam basa terbaik pada percobaan kami adalah ekstrak mahkota bunga sepatu karena ketika dilarutkan dengan larutan basa menunjukan gejala dengan perubahan warna menjadi hijau. Dan ketika dilarutkan dengan larutan asam akan menunjukan gejala dengan berwarna merah. 
PEDULI: Jurnal Ilmiah Pengabdian Pada Masyarakat, 2020, Vol.4, No.1

ISSN: 25974653. e-ISSN:25974688

http://peduli.wisnuwardhana.ac.id/index.php/peduli/index

Berdasarkan angket yang disebarkan pada siswa, menganalisa hasil kegiatan belajar dengan metode praktikum, diperoleh hasil bahwa sebgaian besar siswa merasa sangat puas dengan pembelajaran yang dilakukan.

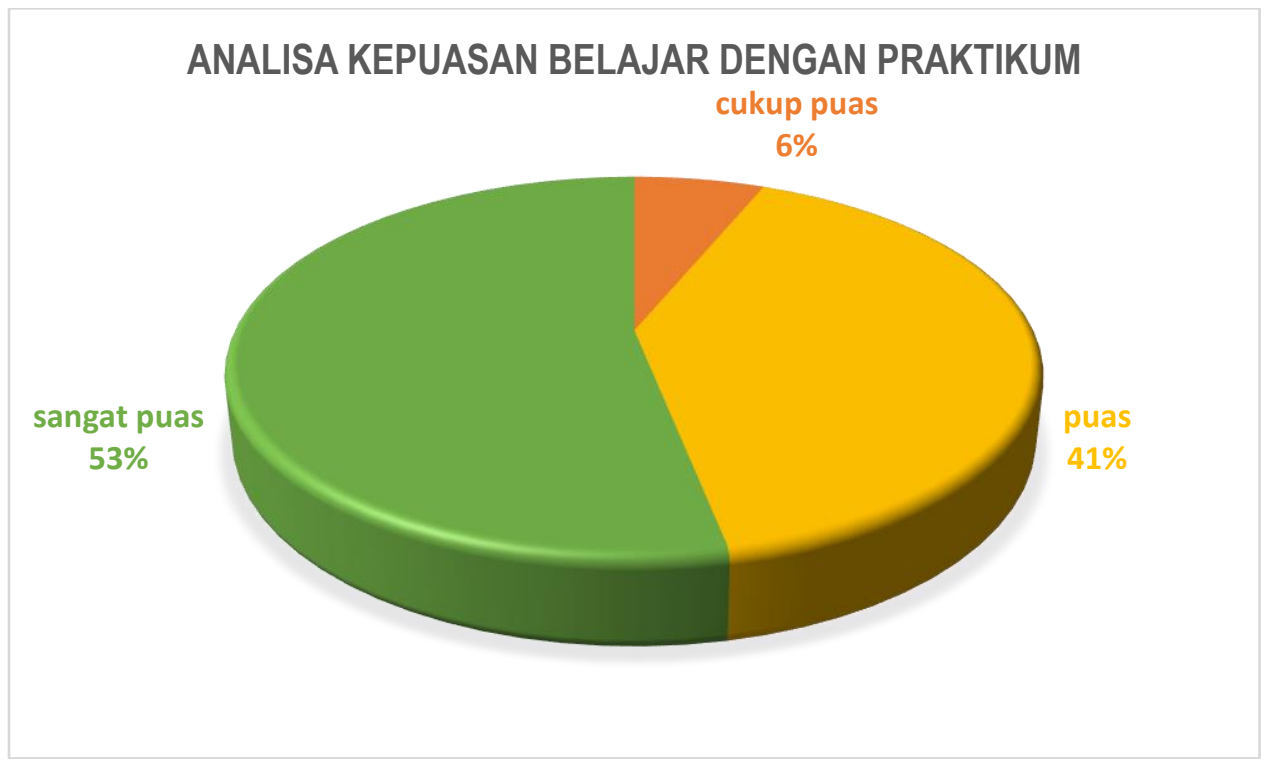

Data diagram pie diatas menunjukkan bahwa tingkat kepuasan siswa menggunakan pembelajaran dengan pratikum pada materi pengujian zat asam basa dengan indicator alami menunjukkan respon positif. Banyak yang menyampaiakan siswa lebih bersemangat dan dapat lebih memahami materi.

\section{KESIMPULAN}

Kegiatan pengabdian masyarakat di wilayah sekolah khususnya pada siswa merupakan salah satu tanggungjawab dosen yang memiliki kemampuan dibidangnya, sehingga diharapkan dapat memberikan solusi pada mitra, yaitu sekolah SMAN 1 Singosari khususnya pada mata pelajaran kimia, pada materi ajar indikator asam basa. Hasil yang dicapai pada program ini adalah adanya solusi belajar yang menarik dan meningkatkan kemampuan siswa untuk mengkonstruksi pengetahuan secara mandiri.

\section{DAFTAR PUSTAKA}

Arifin, M. 2003. Common Textbook Strategi Belajar Mengajar Kimia. Bandung: Jurusan Pendidikan Kimia FPMIPA UPI.

El Islami, R. A. Z., Nahadi, N., \& Permanasari, A. (2016). MEMBANGUN LITERASI SAINS SISWA PADA KONSEP ASAM BASA MELALUI PEMBELAJARAN INKUIRI TERBIMBING. Jurnal Penelitian Dan Pembelajaran IPA. https://doi.org/10.30870/jppi.v2i2.662 
PEDULI: Jurnal Ilmiah Pengabdian Pada Masyarakat, 2020, Vol.4, No.1

ISSN: 25974653. e-ISSN:25974688 http://peduli.wisnuwardhana.ac.id/index.php/peduli/index

Fitriana, N. (2018). Penerapan Model Pembelajaran Blended Learning Pada Mata Kuliah Pemisahan Kimia Materi Kromatografi Untuk Meningkatkan Kualitas Belajar. Erudio Journal of Educational Innovation.

Fitriana, N. F., Yuniwati, E. S., \& Ikawati, A. I. (2019). PELATIHAN DAN PENDAMPINGAN "BOCAH GIMMICK" PAUD/TA CUT NYAK DIEN KELURAHAN BUNULREJO KECAMATAN BLIMBING KOTA MALANG. Jurnal Abdimas BSI: Jurnal Pengabdian Kepada Masyarakat. https://doi.org/10.31294/jabdimas.v2i2.5837

Marta, M. H. C., Suganda, O., \& Widiantie, R. (2018). UPAYA MENINGKATKAN KETERAMPILAN PROSES SAINS MELALUI METODE PRAKTIKUM BERBASIS MODIFIED FREE INQUIRY (MFI) PADA KONSEP ANIMALIA DI KELAS X MIPA. Quagga: Jurnal Pendidikan Dan Biologi. https://doi.org/10.25134/quagga.v10i01.802

Rahmawati, R., Nuryanti, S., \& Ratman, R. (2017). Indikator Asam-Basa dari Bunga Dadap Merah (Erythrina crista-galliL.). Jurnal Akademika Kimia. https://doi.org/10.22487/j24775185.2016.v5.i1.7997

Suryaningsih, Y. (2017). Pembelajaran Berbasis Praktikum Sebagai Sarana Siswa Untuk Berlatih Menerapkan Keterampilan Proses Sains Dalam Materi Biologi. Jurnal Bio Education. 